\title{
Teacher and Administrator Views on School Principals' Accountability
}

\author{
Turkan Argon ${ }^{a}$ \\ Abant Izzet Baysal University
}

\begin{abstract}
The current study aims to identify teacher and administrator views regarding primary school principals' accountability. The case study model, a qualitative research method, was adopted in the study using the holistic single-case design. The working group was composed of a total of 56 individuals, 42 teachers and 14 administrators (11 principals and 3 assistant principals), employed in primary schools centered in the province of Bolu during the 2012-2013 academic year. They were identified via convenience sampling among volunteers. The semi-structured interview form composed of open-ended questions was used as a data collection tool. Content analysis method and digitizing qualitative data were used in data analysis. Research results show that teachers and administrators ascribe the same meaning to the concept of accountability and they believe everybody employed at schools should be held accountable. They also believe that school principals should not only be accountable to their superiors but that the first and foremost rationale for accountability comes from the requirement of principals to undertake their responsibilities properly and in line with the law. They believe that accountability develops a positive climate in schools and that school principals in the Turkish education system don't fully possess the characteristics of accountability. Based on the research results, it can be suggested that administrator assignments should be based on administrator characteristics and that accountability should be prioritized as an important criteria to ensure the employment of administrators who act with accountability in the education system.
\end{abstract}

Keywords: Accountability $\bullet$ Primary school $\bullet$ School principals $\bullet$ Teachers

\section{a Correspondence}

Assoc. Prof. Turkan Argon (PhD), Department of Educational Sciences, Faculty of Education, Abant Izzet Baysal University, Bolu 14280 Turkey

Research areas: Management and organization with specific focus on organizational behavior; Human resources management; School management; Training; Education

Email: turkanargonahotmail.com 
Substantial social, legal, economic, and technological transformations in the developing and changing world have caused organizations to question their managerial styles and gravitate toward new approaches and practices. Management and administration systems of organizations have started transforming (Akyel \& Köse, 2010) and the tendencies toward more transparent and democratic management have increased (Sezer \& Kargin, 2002). The umbrella concept of accountability (Bovens, 2007), which includes modern management principles such as transparency, equality, democracy, competency, and honesty, has started to gain more and more importance as a result of these changes. Accountability, a key concept of modern management, has become one of the critical elements in the approach of such things as reform, transformation, governance, and citizen satisfaction during the restructuring period and it has been placed in the center of democratic systems since it mediates the accountability of authorities towards society and other related parties. The American Institute of Certified Planners (1981) also emphasized the importance of the principle of accountability by addressing this concept along with honesty, justice, and serving public interests in its 1994 report on the Code of Ethics and Professional Conduct.

A series of definitions have been provided for the concept of accountability, a recent focus of interest for researchers. These definitions explain this concept in terms of providing information to an authority related to one's practices (Balc1, 2003; Sözen, 2005), holding a person or an organization responsible to an authority regarding the activities in question (Julnes, 2006; Mulgan, 2000; Peters, 2007), liability to provide answers and explanations (Baş, 2007), and a process for providing explanations to a specific authority about tasks and practices (Mulgan, 2000). Accountability, in more detail, has been defined as the accountability of authorities in an organization to higher authorities regarding the use of authority and responsibility; acting in line with criticisms and demands related to accountability; the need to take responsibility in case of failure, incompetence or infraction of rules (Arcagök \& Erüz, 2006); the use of authority and resources in organizations in line with the law and in accordance with principles of productivity and efficiency; and the presentation of responsibility related to the achievement of specified goals and targets (Sözen \& Algan, 2009). At the same time, accountability is one of the principles that needs to be addressed together with the fundamental principles of consistency, responsibility, equity, transparency, participation, commitment to the legal system, legitimacy and measurability in order to ensure organizational governance (Toksöz, 2008).

Accountability is a tool that ensures organizational managers have appropriate conduct in line with the law and its regulations during the administration of organizational goals. This tool also indicates a social relationship in which the administrator feels required to answer to higher authorities regarding the accuracy of their actions. In this relationship, a higher authority questions the validity of their actions and the sufficiency of information while the party that provides accountability has to answer these questions (Parlak, 2011). In this context, the mechanisms for accountability should be created that clearly provide the procedures and processes to present for determining whether administrators act in line with the expectations of organizations (Sözen, 2005) "Who will be accountable to whom, for what, and with which criteria" should be identified along with the results of actions regarding accountability (Leithwood, 2005). The identification of individuals who will undertake these roles and responsibilities as well as the determination of the extent of these responsibilities will point out the individual who is to be held accountable and identify which parties are to be answered to; it will identify and present the required performance pointing to the reasons for accountability and identify the relationships related to reporting (procedures, strategies and activities) for the method of accountability (Romzek, 2000). Organizations which do not include accountability will display uncertainties, irregularities, and unjust behaviors (Kalman \& Gediklioğlu, 2014). In short, while accountability ensures identifying whether resources are used by managers and employees in line with the purpose of reaching the goals of the organization, it also reveals the deficits and mistakes in services that are provided and points to who is responsible for them.

The public sector seeks to hold bureaucracies accountable to a higher number of citizens, to control the misuse of authority and misconduct via accountability in order to develop democracy, to ensure the use of resources in line with values and the law, and to promote the goal of continuous learning in the field of governance (Balc1, 2003). Some legal regulations on accountability have been undertaken in Turkey in this context led by regulation $\# 5018$, the Public Finance Management and Control Act; \#4982 (4982 Sayılı Bilgi Edinme Hakkı Kanunu, 2003), the Right to Information Act; and \#5176 (5176 Sayılı Kamu Görevlileri Etik Davranış İlkeleri Başvuru Usul ve Esasları Hakkında Yönetmelik, 2005), the 
Regulation on the Principles of Ethical Behavior of Public Officials, Practice Procedures, and Principles. Regulation \#5018 (5018 Sayılı Kamu Mali Yönetimi ve Kontrol Kanunu, 2003) which aims to ensure the use of public resources more effectively, economically, and productively as well as providing financial transparency and public supervision has introduced new regulations to the public financial-management system. Individuals responsible for the use of these resources have been given specific responsibilities in this context and are held accountable to authorities based on these responsibilities. Regulation \#4982 controls the basis for and procedures related to the use of individual rights to access information as a requirement of democratic, accountable, open, and transparent management as well as imposing the obligation on public organizations and institutions to present all manner of information and documentation for the benefit of applicants provided that this is not part of the exceptions listed in the legislation. Regulation \#5176 identifies the principles of ethical behavior that public officials should follow, such as transparency, accountability, impartiality, righteousness, and protection of public interest. Article 20 of this regulation, titled "The Responsibility of Administrators for Accountability," states that public officials are accountable regarding their responsibilities and liabilities in the services they provide, and they should always be open and prepared for public evaluation and audit.

Legal regulations on this topic are generally related to public accountability and financial responsibility. Audits and supervision have been limited to questioning how resources are used and whether different resources have since been created. Even though accountability includes these areas it should be a process that addresses the solution of social problems, transforming the social field via public services in addition to the financial field provided by the organization, administrators, and employees (Tural, 2004). Studies in the field present that while accountability and transparency make positive contributions to an organization in terms of attitudes such as job satisfaction, trust in leaders, the need for independence, feedback regarding tasks, and satisfaction received from responsibilities (Taşçı \& Koç, 2007), these principles are also becoming more and more important in the identification and prevention of bribery and corruption (Polat, 2003). Accountability of institutions included in the Turkish education system is an obligation through law as in all other public organizations. Especially with the socioeconomic changes that occurred after the 80 's, development of the concept of accountability and intense demands from different spheres on the topic of student achievement have increased social pressure on schools and called the responsibility of administrators for student achievement to attention (Balcl, 2011; Korkmaz, 2005) resulting in intensified studies on accountability. The fact that the education system was also affected by this process of change has led to the exploration of different tools that can provide solutions. Accountability policies, which can be regarded as one of these tools, have crucial potential for the harmony between teachers and administrators in public schools which incorporate the comprehensive targets of both policy makers and families (Burt, Lewis, \& Patel, 2010). Therefore, accountability has become one of the most important tools that will lead the system of education to its goals because accountability is based on the realization of student expectations and acquisition of school goals (Anderson, 2005). The aim of accountability in education is to maximize student achievement by increasing the quality of teaching and training activities as well as to identify the extent of achievement of the goals of these organizations through the mechanisms of accountability (Koçak, Turan, \& Aydoğdu, 2012). Accountability in the field of education which serves the development of learning, teaching, and educational methods requires one to claim responsibility for the achievement or failure resulting from current practices (Sato \& Rabinowitz, 2010). The slow, centralized, and unproductive organizational structure of the Ministry in the Turkish educational system is governed by a centralized mechanism affected by various political, administrative, and structural problems. This has, however, deprived schools from having functional accountability policies (Özdemir, Bülbül, \& Acar, 2010). A lack of resources allocated to this field as well as the ineffective and inappropriate use of these resources have resulted in keeping the matter of making schools more effective and productive continuously on the agenda (Hesapcioğlu, 2001).

Although accountability in the system of education is related to everyone involved in the system, it has mainly focused on the behaviors of school administrators (Cooley \& Shen, 2003) and changing their job requirements by adding new responsibilities to their previous roles (Huskey Bone, 2007). In the context of accountability, school administrators are expected to use school resources in the best possible manner and increase the success of the school (Cooley \& Shen, 2003). As a matter of fact, in an age in which accountability is a 
dominant principle, not only the system but also the school administrators should review a multitude of elements again, such as the goals of the school, its priorities, financial position, personnel, programs, educational learning resources, evaluation, and changes (Clarke, Wildy, \& Slater, 2007). In addition, school administrators have critical importance in the connection between policy makers (bureaucrats) and practitioners (teachers) in order to create transformation at the school level (Duggan, 2009). This importance also highlights the effect of the characteristics and behaviors of school principals. The specific characteristics of school principals, such as strengthening teaching and learning at school, supporting professional development, making decisions based on data, and being accountable (Usdan, McCloud, \& Podmostko, 2000), can be regarded as crucial for the success of this process. However, although the number of studies on administrator characteristics in the Turkish education system is increasing in general, the number of studies on accountability in particular are rather limited. Considering the fact that accountability practices should also be implemented in schools in accordance with the law and that school principals are responsible for this, questioning the extent of related practices, identifying the deficits in the process, and taking precautions are primary necessities for success. In this context, this study aims to present the current situation regarding primary school administrators' accountability based on teacher and administrator views as well as to identify the characteristics and behaviors of school administrators who have the attributes of accountability. The study also aims to contribute to the literature in the field of accountability and lead policy makers in the process of making policies related to accountability.

\section{Method}

\section{Research Model}

The current study which examines teacher and administrator views regarding the accountability of school principals adopted a qualitative research design since it systematically investigated the meanings born from experiences (Ekiz, 2003) with the aim to present the perceptions and events both realistically and holistically in a natural environment (Yıldırım \& Şimșek, 2005). The case study, a qualitative research method, was employed and the holistic single-case design was used in the framework of the model. Case studies are a common approach in qualitative research and are used when the researcher wants to probe the targeted situation in depth and detail by focusing on the questions "why" and "what," holistically analyzing one or more cases in their own limitations (environment, time and so forth) (Ekiz, 2003; Yıldırım \& Şimșek, 2005). Holistic single-case designs are utilized to confirm or disprove a theory when a well-formulated theory exists, or for situations that have not been studied before (Ylldırım \& Șimșek, 2005). Case studies examine topics such as decisions, decision-making processes, programs, specific implementation processes, or organizational change along with the commencement and termination points of these topics as their limitations cannot be determined accurately, although it is possible to accomplish this in case studies focusing on only one individual (Yin, 1984 as cited in Ylldırım \& Şimşek, 2005). Like the topics mentioned above, the topic of accountability also includes processes with limits that cannot be exactly determined. Limited studies have been undertaken on this topic in Turkey, and there are no qualitative studies directly involving the accountability of primary school administrators. The study also aims to present whether the concept and process of accountability as accepted in the literature and on legal grounds is practiced as explained in the literature and guided by law. The single case examined by the study includes only primary school administrators from among the school administrators in Bolu.

\section{Working Group}

Purposeful sampling, a sampling method used in qualitative research, was used in the identification of the working group and convenience sampling was utilized as a purposeful sampling method. The researcher chose a closer, easy-to-reach case by using convenience sampling to ensure momentum and convenience (Yıldırım \& Șimșek, 2005). One of the elements that facilitates collection of rich data in qualitative studies is having the participation of volunteers. Another is the ability to reach individuals from whom accurate data can be obtained. In this context, the working group of the study was composed of a total of 56 individuals, 42 teachers and 14 administrators ( 11 principals and 3 assistant principals) who were employed in primary schools in the center of Bolu province during the 2012-2013 academic year. 19 of the participants were female and 37 were male. The necessary information was provided to the working group in May of 2013 and forms were distributed to participants who voluntarily participated in the study. Principals 
and assistant principals who shared their views in the framework of the study were included in the category of school administrators.

\section{Data Collection Tool}

Although it is preferable to use more than one data source in case studies (interviews, focus groups, observations, document analyses, and so forth), these methods can be used alone or in conjunction with each other based on the nature of the problem and the expectations of the researcher. For instance, while some studies utilize only the participantobservation technique as a data collection method, some only use the interview method (Yildırım \& Şimşek, 2005). In this context, the current study employed a structured interview form prepared according to the standardized open-ended question technique in order to identify teacher and administrator views on the accountability of school principals. This form is composed of a carefully written and arranged series of questions which are asked to each participant in the same style and order (Patton, 1987 as cited in Yildırım \& Şimşek, 2005). These forms are often preferred by researchers since they are flexible, have standards, allow in-depth collection of information on a specific topic, facilitate reaching many participants, allow participants to express their thoughts on paper, and provide convenience in data collection and analysis. Participants were asked to provide their views freely in writing to reflect their real thoughts and experiences without being affected by the interviewer so as to prevent any damage that may be caused by interviewer bias or subjectivity (Balc1, 2009; Ekiz, 2003; Yıldırım \& Şimşek, 2005).

The literature was reviewed during the preparation phase of the form and open-ended questions were prepared. The views of three experts in the field of educational administration and supervision in addition to the confirmation of participants were obtained in order to ensure internal validity. In line with feedback from the experts, corrections were made to the form and related explanations as suggested by the Turkish education experts. A pilot implementation was conducted on 5 teachers and 5 administrators who were attending educational administration and supervision master programs, and their feedback was received. Testing the data collection tools with a pilot implementation is directly related to the validity and reliability of the study (Yıldırım \& Şimşek, 2005). It was identified using pilot implementation that the interview questions were easily understood and answered, and the questions did not refer to any topic beyond the content of the question. Data collected from teachers and administrators was compared using related literature on accountability, then it was arranged after an accuracy check and distributed by the researcher herself to the volunteer teachers and administrators in order to collect their views. The interview form includes eight open-ended questions. The questions are as follows:

1) What does the concept of accountability mean to you? 2) Who should be held accountable at schools? 3) What does accountability of school principals mean? 4) Who should school principals answer to? 5) What should school principals be accountable for? 6) What are the characteristics and behaviors of school principals who practice accountability? 7) What are the benefits of having school principals be accountable? 8) Do school principals in the Turkish Education System have the characteristics of accountability?

\section{Data Analysis and Interpretation}

Strategies such as demonstrativeness, transmissibility, consistency, and confirmation (Yıldırım \& Şimşek, 2005) were used to ensure the validity and reliability of the study. In this context, the reality and actuality of the findings obtained in the study, validity of the results in similar environments, consistency of the processes, collection of data with an objective approach, and presentation of results in an objective manner were sought. The data collection and analysis phases were addressed in detail and explained in depth in order to provide readers with a way to generate meanings regarding similar environments and processes, as well as to approach their own practices with more experience and awareness. Also, the data on which the results are based, process of analysis, and coding were supervised under the aim of control.

The content analysis method and digitization of qualitative data were used in data analysis. The basic aim in content analysis is to arrive at concepts and relationships that can explain the obtained data, and this process ensures uniting similar data under specific concepts and themes (Yıldırım \& Şimşek, 2005). Generally, frequencies and percentages are used in interpreting data obtained via content analysis (Büyüköztürk, Çakmak, Akgün, Karadeniz, \& Demirel, 2008). In this context, the research data was analyzed through content analysis and similar data sets were combined under specific concepts and themes, organized, and interpreted in a manner that would be easy for the reader to comprehend. 
Similarities, differences, and relationships among the comments based on the obtained data were taken into consideration and participant views were placed under themes based on the categories of teacher and administrator. The frequency of each view was calculated and the data was digitized. The purpose in data digitization is to increase reliability, decrease bias, and make comparisons among categories (Ylldirım \& Şimşek, 2005). The frequency of each category was displayed along with number of participant views $(n=\mathrm{X})$ in the Tables. While forming the concepts expressed by participants, the tables did not include a total " $n$ " since any one person expressed more than one view. Categories generated after data analysis were reviewed by an expert to ensure reliability. Interesting participant views were directly quoted and interview notes were provided in single quotes. The findings were interpreted in line with theoretical information and results were sought in this manner. The researcher and another educational sciences expert, who was experienced in qualitative research, coded the written data separately in order to ensure reliability (TA, SK). Later, the codes were compared. For reliability calculations, Miles and Huberman's (1994) reliability formula [Reliability= Agreement/ (Agreement + Disagreement) x 100] was used and the reliability of the study was calculated to be $89 \%$. Since the result was higher than $70 \%$, it was accepted as reliable. A percentage of agreement at $70 \%$ or higher is accepted as sufficient for ensuring reliability in data analysis (Miles \& Huberman, 1994). Since it is ethically appropriate to provide confidentiality to the participants, the teachers were coded as $\mathrm{T} 1, \mathrm{~T} 2$, ... T42, and the principals were coded as A1, A2, .. A14 as administrators in presenting the findings.

\section{Findings}

\section{Teacher and Administrator Views Regarding the Concept of Accountability}

An examination of the views on accountability provided in Table 1 shows that the most frequently expressed views that teachers expressed are being responsible $(n=17)$, being accountable $(n=13)$, transparency $(n=7)$ and defending one's own actions $(n=7)$. These are followed by providing information $(n=6)$, acting in line with the law and its regulations $(n=5)$, being open to supervision $(n=3)$, and acting ethically $(n=3)$. The most frequently recurring themes for administrators are being open and transparent $(n=8)$ and providing information $(n=4)$.

Based on these findings, teachers assigned the following meanings to the concept of accountability:

\begin{tabular}{lclc}
\hline $\begin{array}{l}\text { Table } 1 \\
\text { Teacher and Administrator } \\
\text { Accountability }\end{array}$ & & \\
\hline Teacher & $n$ & Administrator & $n$ \\
\hline $\begin{array}{l}\text { Being responsible } \\
\text { Being accountable }\end{array}$ & 17 & $\begin{array}{l}\text { Being open and } \\
\text { transparent }\end{array}$ & 8 \\
$\begin{array}{l}\text { Transparency } \\
\text { Defending one's own }\end{array}$ & 73 & $\begin{array}{l}\text { Providing information } \\
\text { actions }\end{array}$ & 4 \\
Providing information & 6 & $\begin{array}{l}\text { Accepting } \\
\text { responsibility }\end{array}$ & 2 \\
$\begin{array}{l}\text { Acting in line with the } \\
\text { law and its regulations }\end{array}$ & 5 & Being accountable & 2 \\
$\begin{array}{l}\text { Being open to } \\
\text { supervision }\end{array}$ & 3 & $\begin{array}{l}\text { Making participatory } \\
\text { decisions }\end{array}$ & 1 \\
$\begin{array}{l}\text { Acting ethically } \\
\text { Complying with social }\end{array}$ & 3 & Being measurable & 1 \\
norms & 2 & Being ethical \\
$\begin{array}{l}\text { Being open to criticism } \\
\text { Accepting failures }\end{array}$ & 2 & \\
$\begin{array}{l}\text { Acting honestly } \\
\text { Ability to punish }\end{array}$ & 2 & & \\
\hline & 2 & \\
\hline
\end{tabular}

being responsible, being accountable, transparency, defending one's own actions, providing information, acting in line with the law and its regulations, being open to supervision, and acting ethically. Examples of views on accountability follow. Regarding being responsible and accountable, T10 expressed "It is the situation of being able to answer for your work to the people who are affected by it, the people you serve in your field in the organization, and the case of taking responsibility for any negative situation." T31 stated "Providing data and answers about possible problems or questions without faltering and showing appropriate conduct honorably based on rules and laws." As an example for being transparent, T27 said "the ability to explain the correctness of a person's practices and tasks to others under their immediate supervisor's lead, to provide explanations, and to be transparent and open." As an example for providing information, T30 expressed "accountability is the ability to provide explanatory information when needed to individuals or organizations that demand information about all types of tasks and procedures." As an example for defending one's own actions, T16 declared "the ability to defend one's position related to a problem when a problem occurs." Administrators assigned the following meanings to the concept of accountability: being open and transparent, providing information, appropriate conduct, being questioned, accepting responsibility, and so forth. Regarding being transparent, administrator A14 listed "being transparent within the profession and with professional responsibility." 
As an example of being accountable, A9 wrote "For an authority in any organization, (it is about) being accountable to others about one's use of authority and responsibilities." For examples of accountability as far as being questioned, A6 shared "Managers and others (should be) questioned by higher authorities and supervisors based on laws, legislation and regulations." As examples of taking responsibility for one's actions, A4 revealed it to be the "supervision of individuals who make decisions and implement them with their subordinates in terms of the legality of their decisions," and A5 described it as "objectively explaining deficits or negative results after the completion of a task or responsibility and taking responsibility."

\section{People Who Should Be Accountable At Schools}

\begin{tabular}{lclc}
\hline $\begin{array}{l}\text { Table } 2 \\
\text { Teacher and Administrator } \\
\text { Accountable at Schools }\end{array}$ & $n$ & Administrator & $n$ \\
\hline Teacher & 41 & $\begin{array}{l}\text { Everyone employed at } \\
\text { school }\end{array}$ & 9 \\
\hline $\begin{array}{l}\text { Everyone employed at } \\
\text { school }\end{array}$ & 10 & Administrators & 8 \\
$\begin{array}{l}\text { Parents who receive } \\
\text { educational services }\end{array}$ & 7 & Teachers & be \\
$\begin{array}{l}\text { Students who receive } \\
\text { educational services }\end{array}$ & 2 & Janitors & 8 \\
$\begin{array}{l}\text { Parent-teacher } \\
\text { association }\end{array}$ & Civil servants & 3 \\
& Students & 7 \\
& Parents & 2 \\
\hline
\end{tabular}

Examination of the views presented in Table 2 regarding who is accountable at schools shows that teachers $(n=41)$ and administrators $(n=9)$ agree that everyone employed at schools are accountable. In addition, teachers expressed that parents who receive educational services $(n=10)$, students $(n=$ $7)$, and parent-teacher associations $(n=2)$ should also be held accountable, whereas administrators specified that they the administrators $(n=8)$, teachers $(n=8)$, janitors $(n=5)$, civil servants $(n=$ $3)$, students $(n=7)$, and parents $(n=2)$ should all be held accountable.

While the following views of T19, who said "From the janitor to the principal, everyone should be held accountable;" and T37, who stated "All employees of the school should be accountable," are examples of views regarding the necessity for all personnel to be accountable, T27's statement that "First of all, school principals should answer to their superiors and provide information to their colleagues regarding school practices," is related to administrator accountability to superiors. Other views as specified by T30, "All personnel undertaking administrative school tasks and procedures such as teachers, students, and parents, when necessary, should have clear and open accountability on all issues that they are responsible for with one another;" and by T34, "All members of the school should be accountable to one another since teachers, civil servants, janitors, students, and parents have responsibilities towards each other," point to views that include school employees such as administrators, teachers, civil servants, and janitors in this process along with parents and students who benefit from their services. Among the administrators' views pointing to the belief that all individuals employed at schools should have accountability, A1 stated "All stakeholders in the school should provide information to each other and be transparent about their tasks by using their authority and (performing) their responsibilities," and A9 mentioned "All employees in the school should provide information about issues in their own areas." The views of A5, "All employees, even the students and the parents," and A8, "Teachers, students, personnel and administrators should (all) be accountable for their responsibilities and duties," present examples of administrator views that include students and parents in the list of parties that should have accountability in schools.

\section{Accountability of School Principals}

Table 3 presents the most frequently repeated teacher views: ability to explain decisions $(n=10)$, displaying transparent and open management $(n=10)$, having a sense of responsibility $(n=9)$, providing a democratic environment $(n=7)$, providing accurate information to superiors $(n=7)$, and undertaking tasks and procedures that are in line with the law and its regulations $(n=7)$. Administrator views related to the accountability of principals are the ability to answer $(n=6)$, undertaking tasks correctly $(n=5)$, examination of actions in terms of their appropriateness to the law $(n=3)$, being held accountable for actions $(n=3)$, and so forth.

According to teachers, accountability for principals is related to displaying transparent, open, fair and objective management in a democratic environment; explaining their decisions; having a sense of responsibility; undertaking their duties in line with the law and its regulations; and providing accurate information to superiors. Teacher views that can be presented as examples of transparent, open, fair and objective management by 


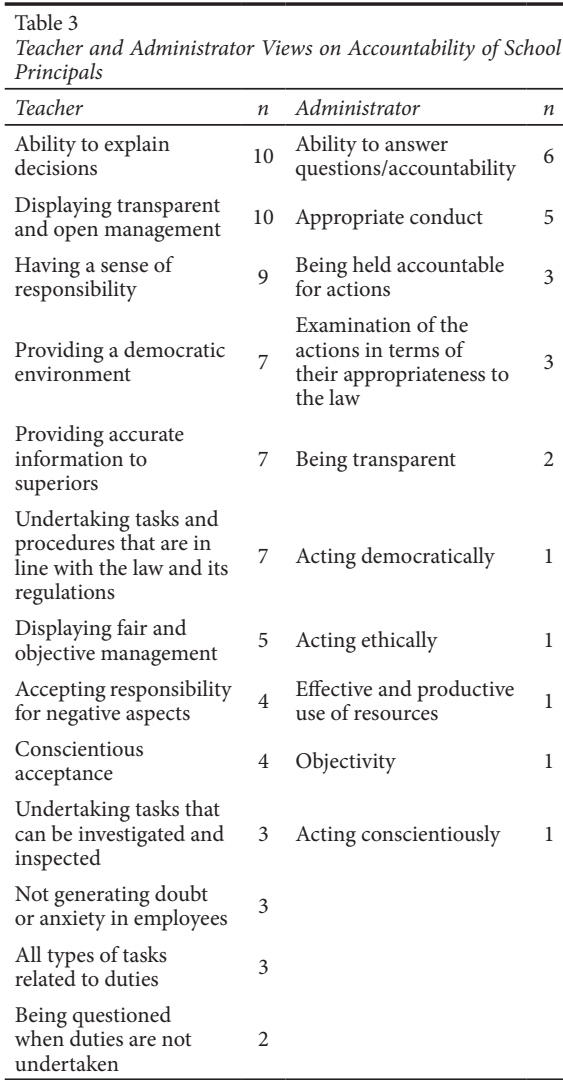

administrators in democratic environments are as follows. T30 said “...has a transparent management approach, is in a position to explain everything to superiors and subordinates when needed, standing behind decisions made." T44 stated "It brings to mind transparency in management." T25 declared "Accountability is a requirement in the approach of transparent management. School principals should have accountability in terms of providing fair management and in terms of whether they use the responsibilities bestowed on them." T23 said "It is adoption of the principle of transparency by the administrators," and T42 stated "Accountability is the transparency, openness, and ability to interpret all material and immaterial tasks in schools in a manner that everyone can see and understand."

Views regarding the accountability of school principals, their sense of responsibility, actions in line with the law and its regulations, and provision of information to superiors are as follows. T5 feels "It is accepting responsibility for any negative situation that can result from school principals' authority and responsibilities." T7 states "Feeling responsibility towards individuals who are affected by the duties the principal undertakes." T12 declares "Individuals who follow the desired behaviors and rules specified in the law and regulations." T26 expresses "The responsibility of school principal towards superiors and subordinates who may be affected by the tasks or duties the school principal undertakes." T10 lastly says "Accountability is in regard to the decisions made in the school for all individuals and organizations that receive services or that are affected by the school in the framework of the law and its regulations based on the general goals of Turkish National Education."

According to administrators, school principals' accountability is related to undertaking tasks correctly, the ability to explain (their decisions), the examination of their actions in terms of appropriateness to the law, and being held accountable for these actions. The following views of A1, "A school principal should be accountable to all stakeholders in all issues related to authority, responsibility and duties," and A14, "Being transparent to parents and superiors about the procedures at school and the ability to explain things," are related to accountability. The following views from A4, "It is the examination of decisions made by the principal in line with the law and regulations;" A12, "Accepting responsibility for all types of negative outcomes (failures, physical deficits, absenteeism, and so forth);" and A9, "Holding principals responsible for their actions," are examples of responsibility for actions, transparency, and appropriateness to the law. The following view of A5, the "Ability to express cause and effect objectively following appropriate conduct," is an example of appropriate conduct.

\section{Individuals and Organizations That School Principals Should be Accountable To}

Table 4 shows that teachers believe that individuals for whom principals should have accountability towards are superiors $(n=33)$, teachers $(n=20)$, parents and students $(n=16)$, and assistant principals $(n=$ $11)$, followed by all related parties $(n=8)$, education inspectors $(n=5)$, and other school administrators $(n=3)$. The most frequently expressed administrator views regarding individuals to whom principals should have accountability are superiors $(n=9)$ and parents $(n=6)$, followed by students $(n=5)$, teachers $(n=2)$, and their own conscience $(n=2)$. According to teachers, school principals should be accountable towards their superiors and teachers, followed by parents and students, their assistants, education 


\begin{tabular}{lcll}
\hline Table 4 & & & \\
Teacher and Administrator & Views Regarding Individuals and \\
Organizations School Principals should be Accountable to & \\
\hline \multicolumn{1}{l}{ Teacher } & $n$ & Administrator & $n$ \\
\hline Superiors & 33 & Superiors & 9 \\
Teachers & 20 & Parents & 6 \\
Parents and students & 16 & Students & 5 \\
Assistant principals & 11 & Teachers & 2 \\
All related parties & 8 & Own conscience & 2 \\
Education inspectors & 5 & Support personnel & 1 \\
Other school & 3 & Inspectors & 1 \\
administrators & 3 & Environment & 1 \\
Society & 3 & & \\
Parent teacher & 3 & & \\
association & 2 & & \\
Their own conscience & 1 & & \\
Subordinates & & & \\
Jurisdiction /Court & & & \\
\hline
\end{tabular}

inspectors, and other school administrators. Similarly, administrators believe that school principals should be accountable towards their superiors, followed by parents, students, and teachers. It is observed that teachers and administrators have similar views about who school principals should be accountable to. The following teacher views can be given as examples of this outlook. T30 wrote "School principals should firstly be accountable to superiors who have higher authority, followed by individuals who are affected by their decisions (teachers, students), and lastly to individuals who undertake tasks and procedures related to school." T36 declared "School principals should be accountable to superiors and all related parties, even the students who are affected by their duties." T44 noted "School principals should be able to openly explain their actions to personnel, students, and parents. They should participate. The formal dimensions of duties are related to administrative superiors." Similarly, the following views can be provided as examples of administrator views as presented in the table. A4 wrote "School principals are independent as far as decisions about school (in line with regulations). They should be accountable to anyone in higher authority as long as these individuals have the right to require information." A6 said "...to students and parents about their actions." A7 acclaimed "According to administrators, school principals should be accountable to superiors, parents, students, teachers, and their own conscience." A9 pondered "School principals should be accountable to administrators to ensure internal and external evaluation. In organizations where organizational culture is experienced, school principals should provide information to colleagues, students, and parents, even though it may not strictly be in the form of accountability."
Justifications for School Principals' Accountability

\begin{tabular}{|c|c|c|c|}
\hline \multicolumn{4}{|c|}{$\begin{array}{l}\text { Table } 5 \\
\text { Teacher and Administrator Views Regarding the Justification } \\
\text { for School Principals' Accountability }\end{array}$} \\
\hline Teacher & $n$ & Administrator & $n$ \\
\hline $\begin{array}{l}\text { Appropriate conduct } \\
\text { in accordance with } \\
\text { the law }\end{array}$ & 15 & $\begin{array}{l}\text { Proving that tasks } \\
\text { undertaken are } \\
\text { appropriate }\end{array}$ & 6 \\
\hline $\begin{array}{l}\text { Democratic } \\
\text { environment }\end{array}$ & 7 & Transparency & 2 \\
\hline Inspection & 6 & Realization of goals & 2 \\
\hline Correct use of authority & 5 & Democratic life & 2 \\
\hline Transparency & 5 & Providing information & 1 \\
\hline Achievement & 5 & Internal supervision & 1 \\
\hline $\begin{array}{l}\text { Preventing practices } \\
\text { that are against the law }\end{array}$ & 4 & $\begin{array}{l}\text { Not interfering with } \\
\text { personal rights }\end{array}$ & 1 \\
\hline Total quality & 3 & $\begin{array}{l}\text { Appropriate use of } \\
\text { resources }\end{array}$ & 1 \\
\hline $\begin{array}{l}\text { Participatory } \\
\text { environment }\end{array}$ & 3 & & \\
\hline $\begin{array}{l}\text { Managing the school in } \\
\text { line with its goals }\end{array}$ & 3 & & \\
\hline $\begin{array}{l}\text { Taking necessary } \\
\text { precautions }\end{array}$ & 3 & & \\
\hline Objectivity & 2 & & \\
\hline Safe environment & 1 & & \\
\hline
\end{tabular}

According to Table 5, the justifications for school principals' accountability are cited by teachers as appropriate conduct in accordance with the law ( $n$ $=15)$, followed by democratic environment $(n=$ 7), inspection $(n=6)$, correct use of authority ( $n=$ $5)$, transparency $(n=5)$, achievement $(n=5)$, and preventing practices that are against the law $(n=4)$. The view most frequently expressed by administrators is proving that tasks undertaken are appropriate $(n$ $=6)$, followed by transparency $(n=2)$, realization of aims $(n=2)$, and democratic life $(n=2)$. Teacher and administrator views both identify appropriate conduct in accordance with the law as the first justification for accountability, followed by democratic environment, transparency, inspection, and realization of goals, all of which are similar justifications.

Examples of views for appropriate conduct in accordance with the law, as well as preventing practices against the law, come from T10, "School principals should be accountable to all parties for presenting that their decisions are of public benefit and in accordance with the law, its regulations, and legislation; that the decisions are not taken arbitrarily," and T7, "...to show that school principals are conducting their duties objectively and scientifically in agreement with the law." Examples of views for appropriate conduct in accordance with the law, preventing practices that are against the law, and transparency can be 
observed in the teacher statements that follow. T30 stated "School principals should be accountable in order to emphasize the accuracy of decisions without offending employers and to reflect the fact that transparent management has been adopted." T13 wrote "School principals should be accountable in order to inspect the appropriateness of their decisions in terms of legislation and laws so as to to prevent illegal practices." T34 responded "School principals should be accountable if they desire achievement, productivity, transparency, participation, and compliance with the rules."

The views of T17, "School principals should have accountability so it is known that continuous inspection will be undertaken," and T41, "School principals should be accountable in order to assess services, evaluate outcomes, and take necessary precautions," point to the rationale of inspection. The view of T18, "School principals should be accountable to increase school achievement and ensure effective communication with staff," is an example of rationale of achievement.

The views of A5, "School inspectors should be accountable for all activities while using their authority. They should be able to present the appropriateness of their actions;" A1, "School principals should act in a transparent manner regarding their conduct and actions. They should show the need for these actions by providing information;" and A11, "School principals should transparently present that their conduct is correct and appropriate. They should be held accountable," can be regarded as examples for justification of the appropriateness of actions and transparency. The views on democratic life can be sampled from A13, who said "The most fundamental characteristic of a democratic system is supervision and accountability."

\section{The Characteristics and Behaviors of a School Principal With Accountability}

Table 6 shows that characteristics of school principals with accountability are similar for both teachers and administrators, and that both groups cite honesty and transparency within the first three characteristics of school principals with accountability. Teachers cite honesty $(n=17)$ and transparency $(n=15)$, followed by fairness $(n=9)$, being open to innovation $(n=9)$, open to criticism $(n=9)$, reliability $(n=8)$, sense of responsibility $(n=8)$, knowledge of management $(n=8)$, being democratic $(n=6)$, open to cooperation and participatory $(n=6)$, and leadership $(n=5)$.
Administrator views include mastery of legislation $(n=6)$, followed by characteristics such as transparency $(n=4)$, honesty $(n=3)$, being open to criticism $(n=3)$, and being democratic $(n=2)$.

The following teacher and administrator views exemplify these characteristics. T35 wrote "A school principal should have a sense of responsibility, be honest, transparent, open to criticism, and courageous." T21 shared "School principals should act according to the law and document all procedures." T36 expressed "School principals should be fair, impartial, open to criticism, honest, and sincere. (They should) have a command of all issues in terms of professional knowledge." T11 stated "School principals should possess leadership qualities, be able to deeply affect society with their conduct, and be able to communicate with individuals from all segments of society." A7 conveyed "Honesty, idealism, commitment to the principle of equality, the ability to undertake and implement tasks well, humanism, fairness, and impartiality." A12 declared "School principals should be trustworthy in conduct, hardworking, and honest. They should make plans about their future conduct."

The behaviors that teachers most frequently cited include standing behind decisions $(n=9)$, acting fairly $(n=8)$, mutual communication ( $n$ $=6)$, respectful manner of speech $(n=6)$, and taking responsibility $(n=5)$, followed by acting honestly ( $n=5)$, acting equally $(n=5)$, acting in a democratic manner $(n=4)$, acting in line with legislation $(n=4)$, providing information $(n=$ $4)$, and making transparent decisions $(n=4)$. According to administrators, behaviors of school principals having accountability include empathy $(n=2)$, effective communication $(n=2)$, acting in line with the law and its regulations $(n=2)$, transparent management $(n=2)$, and being tolerant $(n=2)$. The following teacher views point to the characteristic of standing behind decisions: T36, "School principals should be able to stand behind their decisions and conduct," and T30, "School principals should stand behind their decisions and should be able to clearly reflect their ethical values." Transparent and democratic behaviors are reflected in these teacher statements: T18, "School principals should be respectful towards different views and be democratic," and T37, "School principals should be open, transparent, humanistic to subordinates, and democratic." Being open to cooperation, honesty, and just practices are stressed in the following teacher views: T34, "Powerful actions, believable responses, innovative ideas, being open 


\begin{tabular}{|c|c|c|c|c|c|c|c|}
\hline \multicolumn{4}{|c|}{ Teacher Views } & \multicolumn{4}{|c|}{ Administrator Views } \\
\hline Characteristics & $n$ & Behaviors & $n$ & Characteristics & $n$ & Behaviors & $n$ \\
\hline Honesty & 17 & Stands behind decisions & 9 & Mastery of legislation & 6 & Able to empathize & 2 \\
\hline Transparency & 15 & Acts justly & 8 & Transparency & 4 & $\begin{array}{l}\text { Effective } \\
\text { communication }\end{array}$ & 2 \\
\hline Justice & 9 & $\begin{array}{l}\text { Forms effective } \\
\text { communication }\end{array}$ & 6 & Honesty & 3 & Acts in line with the law & 2 \\
\hline Open to innovation & 9 & $\begin{array}{l}\text { Speaks in a respectful } \\
\text { manner }\end{array}$ & 6 & Good communication & 3 & $\begin{array}{l}\text { Transparent } \\
\text { management }\end{array}$ & 2 \\
\hline Open to criticism & 9 & Takes responsibility & 5 & Open to criticism & 3 & Shows tolerance & 2 \\
\hline Reliability & 8 & Behaves honestly & 5 & Democratic & 2 & Sympathetic & 2 \\
\hline Takes responsibility & 8 & Behaves equally & 5 & Objective & 2 & $\begin{array}{l}\text { Doesn't use fear or } \\
\text { oppression }\end{array}$ & 1 \\
\hline Knowledge of administration & 8 & Accepts criticism & 4 & Responsibility & 2 & Accepts criticism & 1 \\
\hline Democratic & 6 & Acts democratically & 4 & Ethical & 2 & Answers demands & 1 \\
\hline Open to cooperation & 6 & $\begin{array}{l}\text { Acts in line with } \\
\text { legislation }\end{array}$ & 4 & Leader & 1 & Cooperative & 1 \\
\hline Leader & 5 & Proves information & 4 & Crisis management & 1 & Provides advice & 1 \\
\hline Respectful & 5 & $\begin{array}{l}\text { Makes transparent } \\
\text { decisions }\end{array}$ & 4 & Planned & 1 & $\begin{array}{l}\text { Provides internal } \\
\text { supervision }\end{array}$ & 1 \\
\hline Professional knowledge & 4 & Acts with discipline & 4 & Competent & 1 & Motivates personnel & 1 \\
\hline Effective communication & 4 & Cooperative & 4 & Guide & 1 & Academic achievement & 1 \\
\hline Empathy & 4 & Acts dependable & 4 & Accountable & 1 & Acts honestly & 1 \\
\hline Sensitivity & 4 & Patience & 3 & Idealist & 1 & Behaves ethically & 1 \\
\hline Authoritarian & 3 & Acts tolerantly & 3 & Fair & 1 & Ensures competition & 1 \\
\hline Objective & 3 & $\begin{array}{l}\text { Does not indulge in } \\
\text { arbitrary behavior }\end{array}$ & 2 & & & $\begin{array}{l}\text { Uses information } \\
\text { and communication } \\
\text { technology }\end{array}$ & 1 \\
\hline Consistency & 3 & Acts impartially & 2 & & & & \\
\hline Hardworking & 3 & Provides innovations & 2 & & & & \\
\hline Tolerant & 3 & Leadership & 2 & & & & \\
\hline Self esteem & 3 & Acts professionally & 2 & & & & \\
\hline Makes shared decisions & 2 & Is hardworking & 2 & & & & \\
\hline Believes in the law & 2 & $\begin{array}{l}\text { Doesn't have favorites } \\
\text { among staff }\end{array}$ & 1 & & & & \\
\hline Certification & 2 & $\begin{array}{l}\text { Is not involved in } \\
\text { deception }\end{array}$ & 1 & & & & \\
\hline
\end{tabular}

to cooperation, impartiality, making fair decisions, and determination," and T19, "School principals should be accountable without obfuscating documents or using the help of false witnesses." A1 stressed the qualities of empathy and effective communication in the following statement: "A school principal should be sympathetic, empathetic, speak with correct Turkish pronunciation in an understandable manner, and have effective listening skills." Acting in accordance with the law and its legislation are reflected in A9's comment: "School principals should always display ethical behaviors according to the law and its legislation." Not utilizing fear or pressure is reflected in the following statement from A11: "A school principal should approach situations constructively. They should not scare personnel or students, or act in a pressuring manner."

\section{Benefits of School Principals with Accountability}

Table 7 presents the views regarding the benefits of school principals with accountability that are considered crucial: environment of trust ( $n=$ 17) followed by increases in achievement $(n=9)$, increases in quality $(n=7)$, peaceful and sincere environment $(n=7)$, prevention of problems $(n=$ $6)$, democratic environment $(n=5)$, transparent environment $(n=5)$, increase in motivation ( $n=$ 5 ), and effective conduct of teaching and training $(n=5)$. Regarding the most frequently cited view of environment of trust, T29 stated "It would be a safe environment. It develops trust in the principal," T37 said "First of all, it ensures trust in the school," and T9 wrote "A healthy climate of trust is developed in the school environment." The following teacher views exemplify the benefits of school principals with accountability providing 


\begin{tabular}{|c|c|c|c|}
\hline Teacher & $n$ & Administrator & $n$ \\
\hline Environment of trust & 17 & Quality education & 4 \\
\hline $\begin{array}{l}\text { Increase in school } \\
\text { achievement }\end{array}$ & 9 & Safe environment & 4 \\
\hline Increase in quality & 7 & $\begin{array}{l}\text { Comfortable work } \\
\text { environment }\end{array}$ & 3 \\
\hline $\begin{array}{l}\text { Peaceful and sincere } \\
\text { environment }\end{array}$ & 7 & $\begin{array}{l}\text { Transparent } \\
\text { environment }\end{array}$ & 3 \\
\hline Prevention of problems & 6 & Positive climate & 2 \\
\hline $\begin{array}{l}\text { Democratic } \\
\text { environment }\end{array}$ & 5 & Motivated employees & 2 \\
\hline $\begin{array}{l}\text { Transparent } \\
\text { environment }\end{array}$ & 5 & Academic achievement & 2 \\
\hline Increase in motivation & 5 & Decrease in arbitrariness & 2 \\
\hline $\begin{array}{l}\text { Effective education and } \\
\text { training }\end{array}$ & 5 & Effective communication & 2 \\
\hline $\begin{array}{l}\text { Increase in } \\
\text { performance and } \\
\text { productivity }\end{array}$ & 5 & Sharing of responsibility & 2 \\
\hline Development & 4 & Internal inspection & 1 \\
\hline $\begin{array}{l}\text { Cooperation and } \\
\text { participation }\end{array}$ & 4 & Productivity & 1 \\
\hline Positive & 4 & Fair environment & 1 \\
\hline Fair environment & 3 & Decrease in paperwork & 1 \\
\hline Job satisfaction & 3 & Feeling of "we" & 1 \\
\hline $\begin{array}{l}\text { Clear expectations and } \\
\text { targets }\end{array}$ & 3 & & \\
\hline Decrease in conflicts & 2 & & \\
\hline Sense of belonging & 2 & & \\
\hline $\begin{array}{l}\text { Getting rid of } \\
\text { arbitrariness }\end{array}$ & 2 & & \\
\hline $\begin{array}{l}\text { No administrative } \\
\text { loopholes }\end{array}$ & 1 & & \\
\hline
\end{tabular}

transparency, a sense of belonging and team spirit, motivation, and achievement: T8, "Expectations and goals are defined more clearly. Personnel know that their performances will be evaluated justly and motivation is high;" T19, "Doubts are dispersed. Transparency entails trust and achievement;" T22, "The educational environment is founded upon the principles of realism, transparency, and accuracy;" and T34, "A sense of belonging is established in members. It contributes to participation, transparency, and team spirit."

Examples of views on a peaceful and sincere environment follow. T10 said "Trust in the principal increases which results in the creation of a peaceful work environment. Individuals working in this environment work willingly," and T4 said "It creates a sincere educational environment. Since tasks under their responsibility are regular, teachers do not experience administrative aloofness and act more seriously." Administrator views regarding the benefits of school principals with accountability include quality education $(n=4)$, safe environment $(n=4)$, comfortable work environment $(n=3)$ and transparent environment $(n=3)$. Administrator views which express the benefits cited in the table follow. A1 shared "Educational environment and climate are positively affected. Quality of education increases," A2 wrote "Feelings of trust increase. It provides internal supervision, motivates employees, and increases academic achievement," A9 stated "Accountability is a requirement of democratic behavior. When accountability is practiced in educational environments, we teach the concept as well as preserve individual rights and the law in a safe environment. We ensure the practice of truthfulness, honesty, and transparency in educational environments," A8 depicted "When principals are accountable, it is impossible for them to misuse authority. This positively affects education and increases quality," and A11 added "In comfortable work environments, a generation is raised to be forward thinking and able to question, explore, and produce."

\section{School Principals' Characteristics of Accountability in the Turkish Education System}

According to Table 8, 21 teachers stated that school principals do not have characteristics of accountability in the Turkish Education System, 7 expressed that school principals have characteristics of accountability, and 14 stated that accountability is partial. Nine of the administrators stated that school principals have characteristics of partial accountability, four believed that school principals have all the characteristics of accountability, whereas one stated that school principals do not have any characteristics of accountability. Besides, some of participants (both teachers and administrators) answered "yes, no or partially" and they stated no reason to their opinions. Among teacher views focusing on the lack of characteristics of accountability in school principals, the following factors were cited: incompetence of administrators ( $n=10)$, followed by traditional management approach $(n=3)$, the fact that the process is related to superiors and ignores subordinates $(n=3)$, personal relationships and politics $(n=3)$, and a classical inspection approach $(n=2)$. Teachers who believed that school principals have some of the characteristics of accountability emphasized the incompetence of the educational system $(n=3)$, insufficiency of conscientious and legal inspections $(n=3)$, that accountability is practiced on superiors and inspectors, but not valid for subordinates or the environment $(n=2)$, administrator incompetence 
Table 8

Teacher and Administrator Views Regarding School Principals' Accountability Characteristics in Turkish Education System

\begin{tabular}{|c|c|c|c|c|}
\hline & Teacher & $n$ & Administrators & $n$ \\
\hline \multirow{7}{*}{$\begin{array}{l}\text { No } \\
(\text { Teacher }=21 \text {, } \\
\text { administrator }=1 \text { ) }\end{array}$} & Administrators are incompetent & 10 & \multirow[t]{7}{*}{ Acting unilaterally } & \multirow[t]{7}{*}{1} \\
\hline & Traditional management concept & 3 & & \\
\hline & Thinking of superiors, ignoring subordinates & 3 & & \\
\hline & Personal relationships and politics & 3 & & \\
\hline & Classical inspection approaches & 2 & & \\
\hline & Inability to make shared decisions & 2 & & \\
\hline & Avoiding accountability & 1 & & \\
\hline \multirow{7}{*}{$\begin{array}{l}\text { Partially } \\
(\text { Teacher }=14 \text {, } \\
\text { administrator }=9 \text { ) }\end{array}$} & System of education is incompetent & 3 & Selection of school principals is incorrect & 1 \\
\hline & $\begin{array}{l}\text { Conscientious and legal inspection is } \\
\text { insufficient }\end{array}$ & 3 & Politics and personal relationships & 1 \\
\hline & $\begin{array}{l}\text { Towards superiors and inspectors, but not } \\
\text { valid for subordinates and environment }\end{array}$ & 2 & It is only on paper & 1 \\
\hline & Administrator incompetence & 2 & It is regarded as punishment & 1 \\
\hline & Traditional management approach & 2 & Lack of knowledge about the process & 1 \\
\hline & Exists only on paper & 2 & Low level of competence & 1 \\
\hline & Classical inspection approach & 1 & Not completely & 1 \\
\hline \multirow{3}{*}{$\begin{array}{l}\text { Yes } \\
(\text { Teacher }=7 \text {, } \\
\text { administrator }=4 \text { ) }\end{array}$} & Vertical accountability to superiors & 3 & Two inspections and parent teacher meetings & 2 \\
\hline & Laws and regulations & 2 & \multirow[t]{2}{*}{ Administrators have the necessary training } & 1 \\
\hline & Communication skills & 1 & & \\
\hline
\end{tabular}

$(n=2)$, and a traditional management approach $(n$ $=2$ ). Teachers who expressed that school principals have the characteristics of accountability stated that accountability is provided to superiors $(n=3)$, and that the law and regulations already cover this area $(n=2)$. However, it is interesting to note that teachers who believed that school principals had the characteristics of accountability expressed that accountability is a part of the law and regulations and can only be provided to superiors. The following teacher views can be given as examples of teacher statements that focus on the lack of accountability characteristics with rationales. T14 said "Definitely not." T40 expressed "No, supervision is not provided well. The assignment of principals is not based on any necessary criteria." T18 shared "They do not have it because classical inspection methods are still used. School principals answer to their administrators and inspectors." T19 stated "No. Most of them do not have that quality. Once politics is involved, it is too late. Black and white changes depending on location." T28 wrote "No, not if we observe the general situation. When setting up one's own cadre in public offices is so extensive, who can supervise who and who can observe others' mistakes?" T29 put forth "In my opinion, it is definitely no. Only when inspectors arrive are we on hot coals and documentation is prepared." T3 acclaimed "Unfortunately, no. School management is a serious task that requires expertise." The teacher views focusing on the existence of partial accountability follow. T5 wrote "The majority do not have these qualities. The system needs to be developed and renewed." T8 shared "I believe that accountability is scarce in a system where individuals do not receive any education or training in education, where they interpret the concept of management as dominance and have not accepted authority, new management approaches, performance based work or technology." T12 said "It cannot be $100 \%$. The management system is traditional and individuals without a sense of responsibility are in management." T24 stated "Administrators in the Turkish education system are partially accountable. They have the tendency to undertake actions of accountability towards their superiors and inspectors but not their environment or employees." T25 exclaimed "School principals do not have all the characteristics of accountability. Since classical inspection approaches are common in our country, principals are able to present the results as they see fit since the system focuses on the product and not the process."

An example of a teacher's view focusing on the existence of school principals' characteristics of accountability is T10's: “The majority of school principals have the characteristics of accountability. Characteristics related to vertical accountability toward superiors are present."

According to administrator views, two inspections and parent-teacher meetings $(n=2)$ held annually are sufficient for accountability, and administrators have received the necessary training in this regard 
$(n=1)$. An administrator view points to a lack of belief in accountability characteristics in school principals. A1 wrote "I believe that school principals do not have this characteristic. I find it positive that an exam is part of assigning principals, but I don't think it is sufficient on its own. I believe that career and eligibility should be considered objectively."

Examples of administrator views exemplifying the belief that principals have some accountability characteristics follow. A6 said "The majority of principals have partial accountability. Since everything is well controlled on paper by almost all principals, it is assumed that all is well." A12 stated "School principals have become accountable as a result of recent studies. Transparency, however, has not been provided." A7 shared "Regarding accountability as only a punishment creates misunderstandings. The majority of administrators do not have it." Sample statements of positive views are as follow. A9 said "School principals in the Turkish education system have the characteristics of accountability. They have moral values developed since birth and have attended training provided in the organization or as an in-service training activity. The majority of school principals have taken that training." A14 expressed "Definitely yes because the only focus is on the students, education, and transparency."

\section{Discussion}

Accountability, which acts as a tool in the realization of goals in educational organizations by providing evaluation both as a process and as an outcome, is a crucial but not fully practiced process in the Turkish education system. Results of the current study support this statement. It is observed in this study that teachers and administrators assign the same meanings to the concept of accountability such as responsibility and transparency, provision of information, ability to answer, actions conducted according to the law and regulations, as well as ethical behaviors. Examination of the related literature points out that transparency, responsibility, controllability, and answerability are identified as the dimensions of accountability (Koppel, 2005) and that definitions include concepts such as providing explanations (Balc1, 2003; Sözen, 2005), being held responsible (Julnes, 2006; Mulgan, 2000; Peters, 2007), ability to answer, taking criticism and demands into consideration, and accepting responsibility (Arcagök \& Erüz, 2006; Baş, 2007; Mulgan, 2000; Sözen \& Algan, 2009). Accountability in a political and academic context is closely related to concepts such as providing account of one's actions, transparency, equality, democracy, answerability, responsibility, and honesty (Forrester, 2005). Statements provided in this study show that participants also assign similar meanings to accountability as found in the literature. Also, the study results point out that the most frequently used concepts related to the concept of accountability are being responsible, answerability, being open, and transparent. As seen in the literature, these concepts have been emphasized the most regarding the explanations of accountability, and all of them are closely related to accountability.

In order for one individual to be held accountable to another, it is necessary to identify what and why in the accountability process. In this process, individuals are expected to undertake tasks and procedures based on the law and its regulations in accordance with organizational aims, and administrators who are accountable are therefore required to accept responsibility. Administrators with responsibility should display in a clear and transparent manner both to employees and all related organizations and institutions that they undertake their duties and actions on a legal ground, in a manner free from arbitrariness, and without digressing from organizational aims. They should be able to provide explanations and answers when necessary. Although accountability is a general concept, school principals' accountability in the system of education is related to accountability in their practice at school, and the field of practice and evaluation hence becomes more limited in scope. However, considering the fact that schools are public institutions and school administrators are public officials, schools should be accountable through their principals to external authorities regarding the realization of their performance targets as well as to their commitment to legal rules; school principals also need to present that their practices are within the scope of law and that their authority is used fairly and rationally (Balc1, 2003). The basic conditions and indicators of accountability in organizations, such as democratic management (Akyüz, 2006; Parlak, 2011), openness, transparency (Aydın, 2009; Peters, 2007), and taking responsibility even when practices are erroneous (Helmreich, 1998) require this. Since principals are the primary responsible party in school tasks and procedures, their accountability requires them to use their discretion honestly and rationally. Accountability is a tool that ensures school principals' performances in undertaking their responsibilities (Velayutham \& Perera, 2004). The responsibility of principals includes the display of authority in order to undertake 
school activities, to control power, to have freedom for making decisions, and the ability to separate right from wrong (Eryılmaz \& Biricikoğlu, 2011). Principals also have a certain authority and power obtained from law and regulations in order to undertake their responsibilities in their fields. Principals should utilize this power and authority in their administrative practices by displaying transparent, open, fair, and objective management in a democratic environment to make proper decisions. Accountability mechanisms that principals establish at schools positively contribute to the management of administrative processes at the desired level, to the implementation of decision making processes in a democratic manner, and to the reception of feedback related to the system and practices. Research results show that teachers and administrators have similar understandings about school principals' accountability regarding transparent, open, fair, and objective management in a democratic environment; answerability regarding decisions; accepting responsibility for actions that turned negative; being held responsible for their actions, and examination of their conduct based on the law. Also, according to the study on principals' accountability, the concept most cited for both groups is answerability followed by openness and transparency. Answerability is taking responsibility for public services presented by public organizations, the government, and politicians, as well as being responsible for answering these demands and expectations (Mulgan, 2000). This necessitates that school principals provide the related explanations and answers when required.

Openness and transparency is a mechanism that provides the required information to necessary parties about how and for what purposes public resources have been used by principals as well as their outcomes. At the same time, the openness and transparency displayed by principals allow staff to be informed of the conduct and actions undertaken at school as well as generate trust in school management and increase principals' self-esteem (Bilgin, 2005). It should be remembered that trust in the school and the principal will bring many positive characteristics along with it. For instance, there are values that positively affect the operations of an organization where the feeling of trust is dominant and where the employees in these organizations are treated within the framework of ethical principles (Teyfur, Beytekin, \& Yalçınkaya, 2013).

Participants in the study have a common view that everyone employed at schools including principals, teachers, and civil servants- even janitors, students, and parents receiving educational services, should be accountable. The only difference in views is the inclusion of parent-teacher associations by teachers in the accountability process. Therefore, both individuals who receive and provide services are included in the process, and it is highly crucial in the realization of aims. While schools provide students with desired behaviors in the framework of the curriculum, they also prepare them for life in society. Similar to the participation of the whole school staff, participation of the family is very important to the success of the school. Mechanisms of accountability question whether schools ensure acquisition of the highest student achievement by increasing the quality of educational activities, the realization of school aims, for example. School principals are individuals who have important roles in this process; they support teachers' professional experiences with their attitudes and behaviors, provide cooperation and improvements in their practices, and increase student achievement (Normore, 2004). However, principals are not sufficient for this achievement on their own. Teachers and even students should be responsible agents in school principals' accountability as well (Bracci, 2009). School accountability is the assessment of principals, teachers, students, and the school performance as a whole based on predetermined criteria, holding everyone responsible for their own performance and providing sanctions or awards as a result of performance assessment (Duke, Grogan, Tucker, \& Heinecke, 2003). This requires the participation of students in the process along with school staff. Parents are also included in this process based on student age and developmental level. Recently, total quality management actions in schools as preparation for accountability and strategic plans prepared by schools also pointed to the need that everyone should participate in the process. The opinions of participants in the current study also support this view.

When the accountability process is examined in terms of the individuals to whom school principals should be accountable, study results show that participants agreed that school principals should answer to more than one individual. School principals should not only be accountable towards their superiors (director of national education, branch manager, and so forth) but also to their colleagues (other school principals, assistant principals), employees (teachers, civil servants, and even janitors), parentteacher associations, students, parents, the society that receives these educational services, and educational 
inspectors. Therefore, school principals should be accountable to everyone regarding the experiences in a school, their actions, and their conduct. Considering the finding that teachers in schools are accountable to principals, colleagues, parents, and students regarding their actions (Bush, 1994 as cited in Yüksel, 2013), it is realized that administrators have a larger number of individuals and organizations that they should be held accountable to. Classifications in the related literature regarding accountability support participant views and provide the list of individuals and organizations that principals should be responsible to. Classification of accountability is based on structures and characteristics. In the framework of structural classification, administrators of a public organization are accountable to authorities in another public organization via horizontal accountability, whereas administrators are accountable directly to the citizens in vertical accountability. Accountability based on characteristics or quality is classified as political, legal, administrative (hierarchical), and public (Aydın, 2009; Balc1, 2003; Gül, 2008). In political accountability, ministers are accountable to the parliament related to the conduct in their own ministries; in legal accountability, administrators prove their actions are legal in courts. Administrative accountability allows administrators in public institutions to present to higher authorities the legality of their actions and that their use of authority is fair and rational. In public accountability, administrators are accountable to all citizens as well as to the individuals who receive services from the organization (Balc1, 2003; Gül, 2008). Based on this classification, school principals are structurally accountable to parents and society in the vertical dimension and to the director of national education and other authorities such as branch managers in the horizontal dimension. In terms of qualities and characteristics, they are accountable to higher authorities such as the director of national education and its branch managers; to students, parents, and the society at large in the public dimension; and to inspectors and the legal system in the dimension of legal accountability. Therefore, participant views support the literature related to which individuals and organizations school principals should be held accountable to.

According to the participants, the first rationale of accountability is the appropriate and accurate conduct of duties based on the law. This rationale is followed by others such as democratic environment, transparency, supervision, and realization of aims. In addition to daily routine tasks, school principals have many responsibilities in school, administratively speaking. According to Lyons and Algozzine
(2006 as cited in Batsell, 2013), responsibility of accountability in education is one of these responsibilities. Considering that accountability includes characteristics such as control, the obligation to provide information, accurate record keeping, formal identification of responsible parties, providing explanations about what has or has not been done, accepting responsibility, acknowledging appreciation or accusations, and facing rewards or punishments (Stoker, 1999 as cited in Balc1, 2003), school principals are expected to undertake many actions under the responsibility of accountability. Principals should also present that they undertake their duties accurately in a democratic, transparent, fair, participatory manner without interfering with personal rights as well as in accordance with the law. As these increase the prestige, respectability, and success of school principals, the school will also become a trusted and healthy environment and organizational success will increase. Similarly, Ramsey (1999) stated that school administrators are accountable for the following issues: protecting the citizenship and human rights of all individuals and staff, avoiding illegal conduct, undertaking responsibilities with honesty and righteousness, ensuring a safe and healthy environment for personnel and students, avoiding discrimination, avoiding falsehoods and deceptive behavior, placing importance on the principle of justice, developing discipline, trusting in success, and continuously working for the best. In this context, it can be claimed that the research results agree with the related literature.

Teacher and administrator views are similar regarding the characteristics, qualities, and behaviors of school principals with accountability. According to both participant groups, honesty and transparency are the leading characteristics of school principals with accountability. These qualities are followed by fairness, reliability, objectivity, being democratic and participatory, openness to criticism, sense of responsibility, effective communication skills, knowledge of administration and management, as well as leadership qualities, all of which are positive characteristics. The obtained results regarding behaviors of school principals with accountability are in line with the specified qualities as well. Having mutual and positive communication with all at school, acting honestly, accepting criticism, acting in accordance with legislation, making transparent decisions, cooperating, displaying participatory behavior, and being tolerant are all behaviors that agree with the behaviors of school principals with accountability. 
Leadership, cooperation, communication, measurement, and assessment are elements included in all successful accountability systems (Öztürk, 2013). School principals with accountability are expected to achieve the best possible results by using school resources (Lock \& Lummis, 2014). The characteristics of school principals are crucial in successfully undertaking these responsibilities. Creating a culture by developing and enriching staff knowledge and skills, holding various units of the organization together based on the principle of productivity, and ensuring the dominance of accountability for staff are among the roles of school principals (Elmore, 2000). Characteristics and behaviors of principals are rather effective in generating a positive school climate and in ensuring that all staff members work together as a team with trust. Fair and transparent decisions and practices in democratic environments will positively affect staff perceptions toward the work environment. Transparency and mechanisms of openness created under accountability give the right to staff to participate in management, supervise, object, and correct mistakes (Eryllmaz, 2005). They ensure the formation of a management system in which democracy is healthily implemented, basic rights and freedoms are not suppressed, and deficits and errors in management are voiced openly and comfortably (Aydin, 2009). Such a system will motivate staff and increase their performance. Considering that accountability in education is based on the development of teaching by holding the school, school region, and teachers accountable for the achievement and performance levels, as well as on increasing students' expectations from education (Forrester, 2005), it can be claimed that one of the most important roles of school principals for a positive school climate and culture is accountability. A reliable, fair, and transparent climate is ensured with the help of school principals who have accountability. Arbitrariness decreases and staff members comfortably work with motivated team spirit in a peaceful and sincere environment. School climate and productivity is positively affected to ensure a quality education, and therefore job satisfaction and academic achievement are acquired. Research results support these outcomes as well. However, according to the current study, school principals in the Turkish education system are not at the desired level in terms of the characteristics of accountability. Careful examination of the results has shown that according to the majority of teachers, school principals either do not have or partially possess these qualities, while administrators believe that school principals partially possess these characteristics. The rationales of teachers who believe school principals do not have the characteristics of accountability are the incompetence of the education system, insufficiency of conscientious and legal inspection, incompetence of administrators, traditional management and inspection approaches, and the fact that the process is related to superiors, ignoring subordinates in favor of personal relationships and politics. Administrators, on the other hand, believe that the lack of characteristics in terms of accountability relate to avoiding the law and its regulations, undertaking conduct unilaterally not based on specified legislation, mistakes in assignments related to school principals, politics and personal relationships, the belief that sufficiency is when all is well on paper, regarding the accountability process as a punishment, and a lack of knowledge about the process. However, it is interesting to note that teachers who believe that school principals have characteristics of accountability expressed that accountability is included in the law and its regulations, and can only be provided to superiors. This finding may point to a lack of knowledge on the part of teachers about accountability and the accountability process. The fact that administrator views are more positive compared to those of teachers may be related to administrators perceiving themselves in a better light than the real situation and that the number of administrators in the study is lower than that of teachers. Although the number of administrators believing that school principals who have the characteristics of accountability is low, their views are rather significant since they believe that two inspections and parent-teacher meetings held annually are sufficient for accountability, and that administrators have received the necessary training in this regard. As the number of training programs provided to principals by the Ministry for accountability is not even near sufficient, annual inspections and parent-teacher meetings can only be regarded as a part of the process. The ambivalent teacher views found in Argon, Uylas, and Yerlikaya's (2014) study on accountability practices in the Turkish education system as well as Güçlü and Kilınç's (2011) result that school administrators do not have high levels of success in performing behaviors related to accountability support the findings of this study. Traditional management and inspection approaches cited by the participants can be regarded as the main obstacles facing the process of accountability today. The responsibility of traditional accountability in public management used to be undertaken via supervisory methods. These methods included research, interviews, and questioning led by legislative powers, hierarchical control, and supervision by ministries and public administrative branches; it also included investigations and proceedings (or trials) led by judicial authorities as well as the investigations 
and supervisions managed by higher supervisory boards (Haque, 2000). Therefore, accountability was regarded as a topic limited to financial issues, examined in terms according to legal requirements and administrative processes, and the focus was on results. However, accountability has allocated many responsibilities to administrators in organizational life as well as the previously specified points, and has required focusing on the process as well as the results. When the characteristics and behaviors of a school principal with accountability are regarded in general, it is seen that principals need to shoulder more responsibilities today in order to ensure effectiveness and productivity in educational environments according to the requirements of the modern era. For the success of the system, it is not sufficient that school principals be solely accountable. Taking into consideration the basic principles of holding schools responsible for achieving higher performance standards, for supporting schools in strengthening their capacities to provide quality education and increasing the quality and quantity of performance results, primarily student achievement (Hoy \& Miskel, 2010), it can be realized that not only individuals who answer to others but also the individuals who ask the questions should be equipped with these characteristics. This fact is crucial in terms of the effectiveness and productivity expected from the education system.

\section{Suggestions}

Teachers and administrators assigned common meanings to the concept of accountability. Similarly, teachers and administrators agreed that everyone employed at schools should be held accountable. Accountability of school principals is related to displaying transparent, open, fair, and objective management in a democratic climate; explaining the decisions taken at school; accepting responsibility for negative outcomes; and being responsible for the legal appropriateness of actions and conduct. All participants agreed that school principals should not only answer to one authority but to several individuals. School principals should be accountable to their superiors (the director of national education, branch managers, and so forth), colleagues (other school principals, assistant principals), employees (teachers, civil servants, and even janitors), parentteacher associations, students, parents, the society that receives educational services, educational inspectors, and the legal system. The main rationale for school principals to have accountability is to accurately conduct their duties according to the law, followed by democratic climate, transparency, supervision, and realization of aims. According to the participants, honesty and transparency are the leading characteristics of school principals with accountability, followed by fairness, objectivity, openness to innovations and criticism, reliability, mastery of legislation, sense of responsibility, knowledge of management and profession, being democratic, openness to cooperation, and leadership. The behaviors of school principals with accountability include standing behind their decisions; behaving in a democratic, honest, equal, and fair manner; communicating effectively; talking respectfully; taking responsibility; accepting criticism; acting in accordance with the law and its regulations; providing information; making transparent decisions; and avoiding feelings of fear or the use of oppression. Accountability of school principals increases the quality of education; ensures academic achievement; promotes participation in a comfortable, peaceful and sincere climate; creates a cooperative environment of trust; provides job satisfaction by increasing staff motivation and productivity; and ensures the development of a positive climate in a democratic, transparent, and fair environment by removing arbitrariness. However, the characteristics of school principals related to accountability are not at the desired level in the Turkish education system. According to teachers, this is caused by the incompetence of the education system; insufficient conscientious and legal inspections; incompetency of administrators; traditional management and inspection approaches; the fact that the process is related to superiors while ignoring subordinates, personal relationships, and politics; and a lack of common decisions. Administrators, however, believe that the lack of characteristics in terms of accountability is related to avoidance of the law and its regulations, undertaking conduct unilaterally and not based on specified legislation, politics and personal relationships, regarding the process of accountability as a punishment, and lack of administrator competency.

Suggestions developed in line with the findings obtained in the study are as follows: realistic and applicable policies should be developed in the Turkish education system in order to ensure functionality for accountability practices. In addition to making legal arrangements in schools related to accountability, schools should include practices and activities that will disseminate the concept of accountability. For instance, at the end of semesters, school principals, assistant principals and teachers should present their conduct for the year to their colleagues in a meeting and 
explain what has or has not been done in an open and transparent manner as well as answer all questions. With this method, it can be possible to hold everyone accountable and prevent negative situations or doubts in the minds of stakeholders. In addition, communication methods and channels should be established to popularize and generalize accountability in schools, and all staff should be provided information about these channels to ensure the functionality of these methods. Teachers and administrators should be provided with training on the accountability process as well as practice in the form of seminars and conferences. School administrators especially should be enlightened during these training programs about their roles and responsibilities in practicing accountability at school. Administrator competences should be taken into consideration, and accountability should be included among the important criteria in assigning administrators. Politics and personal relationships should be avoided in education. The concept of accountability is a topic which needs to be explored and studied by using larger and different universes within the education system.

\section{References}

4982 Sayılı Bilgi Edinme Hakkı Kanunu. (2003, October 24). T.C. Resmi Gazete, 25269.

5018 Sayılı Kamu Mali Yönetimi ve Kontrol Kanunu. (2003, December 24). T.C. Resmi Gazete, 25326.

5176 Sayılı Kamu Görevlileri Etik Davranış İlkeleri Başvuru Usul ve Esasları Hakkında Yönetmelik. (2005, April 13). T.C. Resmi Gazete, 25785.

Akyel, R., \& Köse, H. Ö. (2010). Kamu yönetiminde etkinlik arayışı: Etkin kamu yönetimi için etkin denetimin gerekliliği. Türk İdare Dergisi, 466, 9-24.

Akyüz, K. (2006). Kamusal hesap verebilirlik ve medya (Master's thesis, Kocaeli University, Kocaeli, Turkey). Retrieved from https://tez.yok.gov.tr/UlusalTezMerkezi

American Institute of Certified Planners. (1981). Code of ethics and professional conduct (V. II-X). Washington DC, MD: Author. Retrieved from http://connection. ebscohost.com/tag/AMERICAN\%2BInstitute $\% 2 B$ of $\% 2$ BCertified\%2BPlanners

Anderson, J. A. (2005). Accountability in education. Education policy series 1. Stedi Média: UNESCO.

Arcagök, M. S., \& Erüz, E. (2006). Kamu mali yönetimi ve kontrol sistemi. Ankara: Maliye Hesap Uzmanları Derneği Yayınları.

Argon, T., Uylas, S. D., \& Yerlikaya, S. (2014, June). Türk milli eğitim sisteminde hesap verebilirlik uygulamaları ve örgütsel sinizme yönelik ilk ve ortaokul öğretmenlerinin görüşleri. Paper presented at VI. Uluslararası Katılımlı Eğitim Denetimi Kongresi, Yıldız Teknik Üniversitesi ve TEM-SEN, İstanbul, Turkey.

Aydın, A. H. (2009). Türk kamu yönetimi. Ankara: Seçkin Yayıncilik.

Balc1, A. (2003). Kamu yönetiminde hesap verebilirlik anlayıșı. In A. Balcı, N. K. Öztürk \& A. Nohutçu (Eds.), Kamu yönetiminde çağdaş yaklaşımlar-sorunlar, tartışmalar, çözüm önerileri, modeller, dünya ve Türkiye yansimaları (pp. 115-133). Ankara: Seçkin Yayınları.

Balcı, A. (2009). Sosyal bilimlerde araștırma. Ankara: Pegem A Yayıncilik.

Balcı, A. (2011). Eğitim yönetiminin değişen bağlamı ve eğitim yönetimi programlarına etkisi. Eğitim ve Bilim, 36(162), 196-208.

Baş, H. (2007). Hesap verme sorumluluğu ve kamu mali yönetimi ve kontrol kanunu. Retrieved from http:// maliyesempozyumu.pamukkale.edu.tr/hasanbas.pdf

Batsell, H. (2013). High school principals in the vortex: Accountability, autonomy, and social justice (Doctoral dissertation, Arizona State University). Retrieved from http://repository.asu.edu/attachments/110527/content/ Batsellasu0010E12945.pdf

Bilgin, M. H. (2005). Kamu yönetiminde yeniden yapılanma tartışmaları. Kadir Has Üniversitesi I.I.I.B.F. Perşembe Konferanslarl (pp. 29-52). Retrieved from http://www.rekabet.gov.tr/

Bovens, M. (2007). Analysing and assessing accountability: A conceptual framework. European Law Journal, 13(4), 447-468. Retrieved from http://dspace.library.uu.nl/ handle/1874/35005

Bracci, E. (2009). Autonomy, responsibility and accountability in the Italian school system. Critical Perspectives on Accounting, 20, 293-312.

Burt, I., Lewis, S. V., \& Patel, S. H. (2010). Increasing accountability in school-led anger management groups: $A$ push for equity. Retrieved from http://www.counseling. org/docs/default-source/vistas/vistas2010article 56.pdf?sfvrsn=9

Büyüköztürk, S., Çakmak, E. K. Ö., Akgün, E., Karadeniz, Ş., \& Demirel, F. (2008). Bilimsel araştırma yöntemleri. Ankara: Pegem Akademi Yayınları.

Cooley, V. E., \& Shen, C. (2003). School accountability and professional job responsibilities: A perspective from secondary principals. NASSP (National Association of Secondary School Principals Bulletin), 87(634), 9-25.

Duggan, M. (2009). School accountability in the Western Australian public school sector: Perceptions of leaders in the field (Master's thesis, Murdoch University, Perth Western Australia). Retrieved from http://researc hrepository. murdoch.edu.au/3000/1/01Front.pdf

Duke, D., Grogan, M., Tucker, P., \& Heinecke, W. F. (2003). Educational leadership in an age of accountability. Albany: State University of New York Press.

Ekiz, D. (2003). Eğitimde araştırma yöntem ve metotlarına giriș: Nitel, nicel ve eleştirel kuram metodolojileri. Ankara: Anı Yayıncilık.

Elmore, R. (2000). Building a new structure for school leadership. Washington DC, MD: Albert Shanker Ins.

Eryılmaz, B. (2005). Кати уönetimi. İstanbul: Erkam Matbaası. 
Eryılmaz, B., \& Biricikoğlu, H. (2011). Kamu yönetiminde hesap verebilirlik ve etik. İş Ahlakı Dergisi, 4(4), 19-45.

Forrester, E. R. (2005). Accountability and the pressures to exclude: A cautionary tale from England. Education Policy Analysis Archives, 13(26), 1-41. Retrieved from http://epaa. asu.edu/ojs/article/view/131/257

Güçlü, N., \& Kılınç, A. Ç. (2011). İlköğretim okulu öğretmenlerinin görüşlerine göre okul yöneticilerinin hesap verebilirlik düzeyleri. NWSA e-Journal of New World Sciences Academy, 6(3), 2110-2122. Retrieved from http:// www.newwsa.com/download/gecici_makale_dosyalari/ NWSA-3594-1-15.pdf

Gül, S. K. (2008). Kamu yönetiminde ve güvenlik hizmetlerinde hesap verebilirlik. Polis Bilimleri Dergisi, 10(4), 71-94.

Haque, M. S. (2000). Significance of accountability under new approach to public governance. International Review of Administrative Sciences, 66(4), 599-617.

Helmreich, R. L. (1998, April). Error management as organisational strategy. Proceedings of the IATA Human Factors Seminar, 1-7, Bangkok, Thailand. Retrieved from http://citeseerx.ist.psu. edu/viewdoc/download? doi=10.1.1.131.2400\&rep=rep1\&type $=$ pdf

Hesapcioğlu, M. (2001). Postmodern küresel toplumda eğitim, okul ve insan hakları. In O. Oğuz, A. Oktay \& H. Ayhan (Eds.), 21 yüzyllda eğitim ve Türk eğitim sistemi (pp. 39-80). İstanbul: Sedar Yayınları.

Hoy, W. K., \& Miskel, C. G. (2010). Eğitim yönetimi teori, araştırma ve uygulama (trans. S. Turan). Ankara: Nobel Yayın Dağıtım.

Huskey Boone, L. (2007). Accountability for the mission: A case study on internal accountability systems at the secondary school level (Doctoral dissertation, Faculty of Drexel University) Retrieved from http://www. pdfph. $\mathrm{com} / \mathrm{pdf} /$ debate-of-standardized-testing-thesis-statement/ Julnes, P. D. L. (2006). Performance measurement an effective tool for government accountability? The debate goes on. Evaluation, 12(2), 219-235. doi:10.1177/1356389006066973.

Kalman, M., \& Gediklioğlu, T. (2014). Okul Yöneticilerinin hesap verebilirliği ile örgütsel adalet arasındaki ilişkinin incelenmesi. Hacettepe Üniversitesi Eğitim Fakültesi Dergisi, 29(2), 115-128.

Koçak, E., Turan, S., \& Aydoğdu, E. (2012). Öğretmenlerin yetki devri, otonomi ve hesap verebilirliklerine ilişkin görüşlerinin incelenmesi. Eğitim ve İnsani Bilimler Dergisi: Teori ve Uygulama, 3(5), 117-148.

Koppell, J. (2005). Pathologies of accountability: ICANN and the challenge of multiple accountabilities disorder. Public Administration Review, 65(1), 94-108.

Korkmaz, M. (2005). Okul yöneticilerinin yetiștirilmesi: Sorunlar-çözümler ve önerileri. Gazi Eğitim Fakültesi Dergisi, 25(3), 237-252.

Leithwood, K. (2005). Educational accountability: Issues and alternatives research report. Retrieved from http:// www.saskschoolboards.ca/research/governance/05-01.pdf

Lock, G., \& Lummis, G. (2014). Complying with school accountability requirements and the impact on school leaders. Australian Journal of Teacher Education, 39(2), 5769. Retrieved from http://ro.ecu.edu.au /cgi/viewcontent. cgi? article $=2264 \&$ context $=$ ajte

Miles, M. B., \& Huberman, A. M. (1994). Qualitative data analysis: An expanded sourcebook. California: Sage.

Mulgan, R. (2000). Accountability: An ever-expanding concept? Public Administration, 78(3), 554-573.

Normore, A. H. (2004). The edge of chaos school administrators and accountability. Journal of Educational Administration, 42(1), 55-77.
Özdemir, S., Bülbül, M., \& Acar, M. (2010). Challenges associated with administrative and professional accountability in the Turkish educational system. In J. Nemec \& B. G. Peters (Eds.), State and administration in a changing world (pp. 271-282) NISPAcee Press.

Öztürk, N. (2013, Kasım). Dünyada yükseköğretim hesap verebilirlik uygulamaları ve Türkiye için bir çerçeve. In 8 . Ulusal Eğitim Yönetimi Kongresi Bildiri Özetleri Kitapçı̆̆ı (pp. 48-49). İstanbul: Marmara Üniversitesi.

Parlak, B. (2011). Kamu yönetiminde yeni vizyonlar. Bursa: Alfa Aktüel Yayınları.

Peters, B. G. (2007). Performance-based accountability. In A Shah (Ed.), Performance accountability and combating corruption (pp. 15-32). Washington DC, MD: The World Bank.

Polat, N. (2003). Saydamlık, hesap verme sorumluluğu ve denetimin etkinliği. Sayıştay Dergisi, 49, 65-80.

Ramsey, R. D. (1999). Lead, follow, or get out of the way: How to be a more effective leader in today's schools. Thousand Oaks, CA: Corwin Press.

Romzek, B. S. (2000). Accountability of congressional staff. Journal of Public Administration Research and Theory, 10(2), 413-446

Sato, E., \& Rabinowitz, S.N. (2010). Evaluation and accountability. In P. Peterson, E. Baker \& B. McGaw (Eds.), International encyclopedia of education (3rd ed., pp. 600606), Oxford, England: Elsevier.

Sezer, Y., \& Kargın, N. (2002). Kamu yönetiminin modernleşmesinde şeffaflaşma sorunu. Türk İdare Dergisi, 74(436), 209-225.

Sözen, S. (2005). Teori ve uygulamada yeni kamu yönetimi. Ankara: Seçkin Yayınları.

Sözen, S., \& Algan, B. (2009). İyi yönetiş̧im (İyi yönetişim araştırma raporu). Ankara: İçişleri Bakanlığı.

Taşçı, D., \& Koç, U. (2007). Örgütsel vatandaşlık davranışıörgütsel öğrenme değerleri ilişkisi: Akademisyenler üzerinde görgül bir araştırma. Anadolu Üniversitesi Sosyal Bilimler Dergisi, 7(2), 373-382.

Teyfur, M., Beytekin, F. B., \& Yalçınkaya, M. (2013). İlköğretim okul yöneticilerinin etik liderlik özellikleri ile okullardaki örgütsel güven düzeyinin incelenmesi (İzmir il örneği). Dicle Üniversitesi Ziya Gökalp Eğitim Fakültesi Dergisi, 21, 84-106.

Toksöz, F. (2008). İyi yönetişimin el kitabı. İstanbul: TESEV Yayınlar1.

Tural, N. K. (2004). Küreselleșme ve üniversiteler. Ankara: Kök Yayıncilık.

Usdan, M., McCloud, B., \& Podmostko, M. (2000). Leadership for student learning: Reinventing the principalship. National Pres Club, 12, 1-2. Washington DC, MD: Institute for Educational Leadership.

Velayutham, S., \& Perera, M. H. B. (2004). The influence of emotions and culture on accountability and governance. Corporate Governance, 4(1), 52-64. Retrieved from http:// www.emeraldinsight.com/journals .htm?articl eid $=873192$

Clarke, S., Wildy, H. \& Slater, C. (2007). International perspectives of principal preparation: How does Australia fare? Leading \& Managing Special Edition, 13(2), 1-14. Paper in: Special edition: Future School Leaders: Images and Challenges. Cranston, N. (ed.). Retrieved from http://search.informit.com.au/documentSummary;dn $=200711307$;res=IELAPA

Yıldırım, A., \& Şimşek, H. (2005). Sosyal bilimlerde nitel araştırma yöntemleri. Ankara: Seçkin Yayınları.

Yüksel, S. (2013). Öğretmen yetiștirmede hesap verebilirlik bağlamında KPSS sonuçlarının değerlendirilmesi. Hacettepe Üniversitesi Eğitim Fakültesi Dergisi Özel Sayı, 1, 404- 420. 